\title{
Farmers Entrepreneurship and Performance of Red Onion Farming in Bantul District
}

\author{
Ulfah Nurdiani ${ }^{1}$, Slamet Hartono ${ }^{2}$, Jamhari ${ }^{2}$ \\ ${ }^{1}$ Student in Agriculture Economic Study Program, Unversity of Gadjah Mada, Yogyakarta \\ ${ }^{2}$ Lecturer in Faculty of Agriculture, University of Gadjah Mada, Yogyakarta
}

\begin{abstract}
The purposes of this study were: (1) To identify the level of onion farmers entrepreneurship in Bantul district, (2) To determine the influence of individual factors, physical, social, economic and institutional environment on the level of farmers entrepreneurship and performance of red onion farming in Bantul district, and (3) To determine the effect of the level farmers entrepreneurship on performance of red onion farming in Bantul district. The method study uses descriptive analytical, which analyzed the data further to find a relationship or ratio between the variables in the theoretical framework of thinking. Data collection using questionnaires previously tested the validity of using Product Moment Correlation and reliability testing using Cronbach Alpha coefficients. Data analysis techniques broadly consists of three stages: a preliminary analysis to calculate individual farm performance indicators (produtifitas, revenue and Private Cost Ratio), descriptive analysis of the percentage of the study variables and analysis of structural equation model (SEM). The research results showed that the level of red onion farmers entrepreneurship in Bantul categorized high with an overall average percentage of $70.87 \%$. Individual factors, physical, social, economic and institutional environment positive and significant impact on the farmers entrepreneurship and performance of farming. The factor that has the greatest positive effect of individual factors followed by the institutional environment. The physical environment and the economy have the same magnitude, while the smallest is the social environment influences. Farmer entrepreneurship positive effect on farm performance and has an important role in mediating the influence of individual and environmental factors on farm performance. These results provide evidence for the idea that entrepreneurial farmers is something that can be grown and can be considered to be a new approach in improving farm performance.
\end{abstract}

Keywords: Entrepreneurship, Performance, Structural Equation Model

\section{INTRODUCTION}

Farm sector (on-farm) research are generally more focused on analyzing farm performance and the determinants of production and income in the technological aspects of cultivation. Farm production is generally more associated with the use of inputs of land, seed, fertilizer, medicine, labor, farmers age and land fertility.

The success of peasant farming in achieving high performance in fact is not only determined by the activities of cultivation techniques but is also influenced by how much the ability of farmers to manage and creation production factors under their control into a profitable business and sustainability efforts. This capability is referred to as entrepreneurship

Farmers entrepreneurship are very important as a new approach in improving farm performance among others based on the entrepreneurial characteristics and also because in the future based farmer with all its limitations either in relation to arable land, technology, capital, management, information and access to markets, farmers should strive to achieve high performance farm in the middle of the business environment is not favorable either because the output market is not conducive, which does not support the nature and related problems with cultivation (Wibowo, 2005).

Entrepreneurship is important for the development of agribusiness (Soetriono, 2006). Entrepreneurship is also important to the process of economic development, including agricultural development. Pressure business environment in the agricultural sector are entering an era of international trade that is free and as if without geographical boundaries, the marketing of agricultural products in the world, including Indonesia entered a period of difficult times so we need entrepreneurs who can compete for the challenge and the opportunities that exist (Priyanto, 2004 ).

The above opinions are explicitly or implicitly suggests that an important entrepreneurship in agribusiness, but the empirical evidence on the 
agriculture sector (especially in on-farm sectors) are so rare. Therefore, farmers need to prove whether entrepreneurship can be an alternative approach in improving farm performance in this study examines farmers and farming of red onion in Bantul district based on the characteristics and potential.

The purpose of this study were: (1) To identify the level of onion farmers entrepreneurship in Bantul district, (2) To determine the influence of individual factors, physical, social, economic and institutional environment on the level of farmers entrepreneurship and performance of red onion farming in Bantul district, and (3) To determine the effect of the level farmers entrepreneurship on performance of red onion farming in Bantul district.

\section{METHODS}

The data used in this study are primary and secondary data. Bantul District was purposively selected as the study site. Sanden and Kretek selected sub as with sub samples were further selected two villages namely Srigading and Parangtritis sample. The study was designed using SEM method approach. According to Hair et al. (1995) in Solimun (2008), there are two ways of determining an appropriate sample size for SEM, namely: (1) 100-200 or (2) as much as 5-10 times the number of estimated parameters. In this study, determination of the number (size) of the sample using the basic approach of the first, which is defined as the number of samples 100 farmers plant ingred in season I 2011 intentionally (purposive).

\section{Validity and Reliability Test for Questionnaire}

The validity test of the items was measured using Product Moment Correlation analysis, while there liability test was done by using Cronbach Alpha Formula (Arikunto, 2002). Calculation of validity and reliability with SPSS 20.0 for windows.

\section{Structural Equation Model Analysis}

The analysis is divided into two parts: a confirmatory factor analysis (Confirmatory Factor Analysis/CFA), which aimed to test the constructs unidimensionalitas of exogenous and endogenous constructs that will confirm whether the observed variables reflect factors analyzed and the analysis of SEM (Structural Equation Model ) by building a theoretical model is presented in Table 1. and the model presented in Figure 1.

\section{RESULTS AND DISCUSSION}

\section{Validity and Reability Test}

The validity of the statement items to measure of farmers perceptions tophysical, social, economic, and institutional environmental factors variables and entrepreneurial onion farmers in Bantul. The results showed all the items valid because the wholes statement item questionnaire obtained r-count (corrected item total correlation) greater than the value of r-table.

The values for reliability testing using Cronbach alpha coefficients scores derived from questionnaire items were valid. The questionnaire has high reliability coefficients obtained if $>0.60$ (Ghozali, 2002). Based on reliability test results also showed that the questionnaire used in the data collection reliable because the Cronbach alpha coefficient greater than 0.6.

\section{Individual Factors and Perceptions of Farmers Against Physical, Social, Economic and Institutional Environmental Factors}

\section{Individual Factors}

Individual factors in this study is a latent variable measured by the indicators of age, formal education, farming experience and household size. Based on Table 2. it can be seen that the onion farmers dominated by middle age is between 3655 years of age where age is still productive. Age is still earning an internal environmental factors that allegedly could be supporting the development of the entrepreneurial spirit because it is still potential to develop themselves and the farm.

The majority of the onion farmers of education is high school, followed by $43 \%$ with $31 \%$ SMP. This shows that farmers have adequate education and it is expected to be a supporter of the development of the entrepreneurial spirit that farmers are better able to manage the farming and be able to respond to market demands.

Onion farmers farming experience dominated $>20$ years are followed by $28 \%$ and $24 \% 16-20$ years. While farming experience $\leq 5$ years only $7 \%$. The description indicates that most farmers had farming experience enough red onion. The more the number of family members the costs incurred to meet the needs of farmers will also increase, although not always so. However, a 
growing number of family members covered will be more motivating farmers to be more successful in farming. Based on Table 2. predominantly peasant family size of $2-3$ people is $68 \%$, followed by $4-5$ people is $24 \%$.

Table 1. Theoretical Model Building Research

\begin{tabular}{lll}
\hline \multicolumn{1}{c}{ No } & \multicolumn{1}{c}{ Variables } & \multicolumn{1}{c}{ Indicator } \\
\hline 1. & Individuals $\left(\xi_{1}\right)$ & Age $\left(\mathrm{X}_{1}\right)$ \\
& & Formal education $\left(\mathrm{X}_{2}\right)$ \\
& & Farming experience $\left(\mathrm{X}_{3}\right)$ \\
& & Household size $\left(\mathrm{X}_{4}\right)$ \\
\hline 2. & Physical Environment $\left(\xi_{2}\right)$ & Transportation $\left(\mathrm{X}_{5}\right)$ \\
& & Irrigation $\left(\mathrm{X}_{6}\right)$ \\
& & Development of cultivation technology $\left(\mathrm{X}_{7}\right)$ \\
\hline 3. & Social Environment $\left(\xi_{3}\right)$ & Family Support $\left(\mathrm{X}_{8}\right)$ \\
& & Community support $\left(\mathrm{X}_{9}\right)$ \\
& & Government support $\left(\mathrm{X}_{10}\right)$ \\
\hline 4. & Economics Environment $\left(\xi_{4}\right)$ & The development of farm income $\left(\mathrm{X}_{11}\right)$ \\
& & The development of inputs market $\left(\mathrm{X}_{12}\right)$ \\
& & The development of output market $\left(\mathrm{X}_{13}\right)$ \\
\hline 5. & Institutional Environment $\left(\xi_{5}\right)$ & The role of farmer groups $\left(\mathrm{X}_{14}\right)$ \\
& & The role of agricultural extension $\left(\mathrm{X}_{15}\right)$ \\
& & The role of credit agencies $\left(\mathrm{X}_{16}\right)$ \\
\hline 6. & Entrepreneurship $\left(\eta_{1}\right)$ & need for success in farming $\left(\mathrm{Y}_{1}\right)$ \\
& & Confidence $\left(\mathrm{Y}_{2}\right)$ \\
& & Risk taking $\left(\mathrm{Y}_{3}\right)$ \\
& & Innovative $\left(\mathrm{Y}_{4}\right)$ \\
& & Leadership $\left(\mathrm{Y}_{5}\right)$ \\
& & Goal and outcome orientation $\left(\mathrm{Y}_{6}\right)$ \\
& & Market Orientation $\left(\mathrm{Y}_{7}\right)$ \\
\hline 7. & Performance $\left(\eta_{2}\right)$ & Productivity $\left(\mathrm{Y}_{8}\right)$ \\
& & Income $\left(\mathrm{Y}_{9}\right)$ \\
& & Competitive Advantage $\left(\mathrm{Y}_{10}\right)$ \\
& &
\end{tabular}

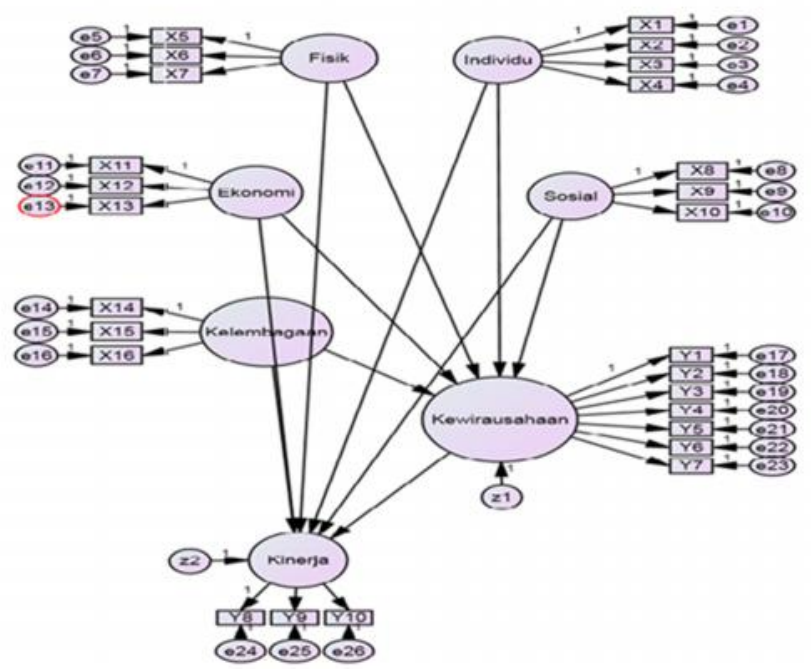

Figure 1. SEM Model Hypothesis

\section{Physical Environmental Factors}

Table 3. indicates that the physical environment is categorized favor with the average percentage of $68.76 \%$. This is because the transport and irrigation support and development of cultivation techniques are quite supportive. The 
condusive condition physical environment will be grow entrepreneurial farmers ultimately expected positive effect on onions farm performance improvement.

Table 2. Description of Individual Factors onion farmers in Bantul $n=100$

\begin{tabular}{llll}
\hline Indicator & Category & Number of People & Percentage (\%) \\
\hline Age & $15-25$ years & 2 & 2 \\
& $26-35$ years & 8 & 8 \\
& $36-45$ years & 38 & 38 \\
& $46-55$ years & 27 & 27 \\
& $>55$ years & 25 & 25 \\
\hline Formal Education & Total & 100 & 100 \\
& No School & 3 & 3 \\
& Elementary & 21 & 21 \\
& Junior High & 31 & 31 \\
& High & 43 & 43 \\
& University & 2 & 2 \\
\hline Farming experience & Total & 100 & 100 \\
& $\leq 5$ years & 7 & 7 \\
& 6-10 years & 21 & 21 \\
& $11-15$ years & 20 & 20 \\
& $16-20$ years & 24 & 24 \\
& $>20$ years & 28 & 28 \\
\hline Household size & Total & 100 & 100 \\
& $0-1$ people & 5 & 5 \\
& $2-3$ people & 68 & 68 \\
& $4-5$ people & 24 & 24 \\
& $>5$ people & 3 & 3 \\
\hline & Total & 100 & 100 \\
\hline
\end{tabular}

Source : Primary Data Processed (2012)

Table 3. Farmers Perception on Physical Environmental Factors, $n=100$

Indicator/Variables $\quad$ Number of People and Percentage Categori

\begin{tabular}{|c|c|c|c|c|c|c|c|}
\hline & \multicolumn{5}{|c|}{ Percentage of Each Category } & \multirow[t]{2}{*}{ of Average } & \\
\hline & VS & $\mathrm{S}$ & ES & NS & DNS & & \\
\hline Transportation & 13 & 73 & 6 & 6 & 13 & 77,80 & $\mathrm{~S}$ \\
\hline Irrigation & 24 & 20 & 12 & 26 & 8 & 67,20 & $\mathrm{~S}$ \\
\hline $\begin{array}{l}\text { Development of } \\
\text { Cultivation technology }\end{array}$ & 4 & 23 & 62 & 11 & 0 & 61,28 & ES \\
\hline
\end{tabular}

Source : Primary Data Processed (2012)

Note: VS (Very Supports), S(Support), ES(enough support), NS(NoSupport), DNS (It Does Not Support)

\section{Social Environmental Factors}

Table 4. showed that based on the average percentage of the overall social environment of $69.69 \%$ and zoned support. That is because the average percentage of family and community support are high, amounting to $82.10 \%$ and $70.27 \%$. Family support and community support for the growth categorized entrepreneurship onion farmers in farming, while farmers perceived government support is only enough to support the average percentage of $56.72 \%$.

\section{Economics Environment}

Table 5. showed that based on the average percentage of the overall economic environment and categorized by $69.40 \%$ support. That is because the average percentage of farm income growth is high at $80.20 \%$ and zoned support. While the perception of farmers to input and output market conditions sufficient to support that the average percentage of respectively $66.20 \%$ and $58.40 \%$. 
Table 4. Farmers Perception on Social Environmental Factors, $\mathrm{n}=10$

\begin{tabular}{|c|c|c|c|c|c|c|c|}
\hline \multirow[t]{2}{*}{ Indicator/ Variables } & \multicolumn{5}{|c|}{$\begin{array}{c}\text { Number of People and Percentage } \\
\text { of Each Category }\end{array}$} & \multirow[t]{2}{*}{$\begin{array}{l}\text { Percentage } \\
\text { of Average }\end{array}$} & \multirow[t]{2}{*}{ Categori } \\
\hline & VS & $\mathrm{S}$ & ES & $\mathrm{NS}$ & DNS & & \\
\hline $\begin{array}{l}\text { The development of } \\
\text { farm income }\end{array}$ & 28 & 56 & 5 & 11 & 0 & 80,20 & $\mathrm{~S}$ \\
\hline $\begin{array}{l}\text { The development of } \\
\text { inputs market }\end{array}$ & 10 & 34 & 54 & 2 & 0 & 66,20 & ES \\
\hline $\begin{array}{l}\text { The development of } \\
\text { output market }\end{array}$ & 15 & 18 & 34 & 10 & 23 & 58,40 & ES \\
\hline & Envi & $\mathrm{nm}$ & & & & 68,26 & $S$ \\
\hline
\end{tabular}

Source : Primary Data Processed (2012)

Note: VS (Very Supports), S (Support), ES (enough support), NS (No Support), DNS (It Does Not Support)

Table 5. Farmers Perception of Environmental Economics Factors, $n=100$

\begin{tabular}{lcccccccc}
\hline \multicolumn{1}{c}{ Indicator/ Variables } & \multicolumn{9}{c}{$\begin{array}{c}\text { Number of People and Percentage of } \\
\text { Each Category }\end{array}$} & $\begin{array}{c}\text { Percentage } \\
\text { of Average }\end{array}$ & Categori \\
& \multicolumn{1}{c}{ VS } & S & ES & NS & DNS & & \\
\hline Family Support & 44 & 47 & 7 & 2 & 0 & 82,10 & S \\
Community support & 16 & 55 & 25 & 4 & 0 & 70,27 & S \\
Government support & 2 & 15 & 59 & 22 & 2 & 56,72 & ES \\
\hline \multicolumn{4}{c}{ Social Enviroment } & & & 69,69 & S \\
\hline
\end{tabular}

Source : Primary Data Processed (2012)

Note: VS (Very Supports), S (Support), ES (enough support), NS (No Support), DNS (It Does Not Support)

\section{Institutional Environmental Factors}

Table 6. showed that based on the average percentage of the overall institutional environment of $69.89 \%$ and zoned support. This is mainly because the average percentage of the role of farmer groups is very high at $86.08 \%$ and categorized very supportive. While the perception of farmers to agricultural extension and credit institutions are sufficiently supported by the average percentage of respectively $66.00 \%$ and $57.60 \%$.

Table 6. Farmer Perceptions on Institutional Environmental Factors, $n=100$

\begin{tabular}{|c|c|c|c|c|c|c|c|}
\hline \multirow[t]{2}{*}{ Indicator/ Variables } & \multicolumn{5}{|c|}{$\begin{array}{l}\text { Number of People and Percentage of } \\
\text { Each Category }\end{array}$} & \multirow[t]{2}{*}{$\begin{array}{l}\text { Percentage } \\
\text { of Average }\end{array}$} & \multirow[t]{2}{*}{ Categori } \\
\hline & $\mathrm{VH}$ & $\mathrm{H}$ & $\mathrm{HE}$ & $\mathrm{L}$ & VL & & \\
\hline Need for success in farming & 55 & 36 & 9 & 0 & 0 & 83,54 & VH \\
\hline Confidence & 37 & 55 & 6 & 2 & 0 & 78,54 & $\mathrm{H}$ \\
\hline Risk taking & 28 & 51 & 19 & 2 & 0 & 75,40 & $\mathrm{H}$ \\
\hline Innovative & 0 & 18 & 26 & 49 & 7 & 51,92 & $\mathrm{HE}$ \\
\hline Leadership & 8 & 58 & 23 & 11 & 0 & 68,47 & $\mathrm{H}$ \\
\hline Goal and outcome orientation & 14 & 66 & 17 & 3 & 0 & 72,27 & $\mathrm{H}$ \\
\hline Market Orientation & 15 & 36 & 42 & 7 & 0 & 66,00 & $\mathrm{HE}$ \\
\hline
\end{tabular}

Source: Primary Data Processed (2012)

Note: VS (Very Supports), S (Support), ES (enough support), NS (No Support), DNS (It Does Not Support)

\section{Farmers Entrepreneurship}

Level of entrepreneurial growers based on each indicator shows diversity. Table 7. shows the level of entrepreneurship onion farmers in Bantul 
once answered the first research hypothesis suggests that the level of entrepreneurship onion farmers in Bantul considered high. It can be seen from the overall average percentage of $70.87 \%$.

Table 7. Onion Farmers Entrepreneurship level in Bantul

\begin{tabular}{|c|c|c|c|c|c|c|c|}
\hline \multirow[t]{2}{*}{ Indicator/ Variables } & \multicolumn{5}{|c|}{$\begin{array}{c}\text { Number of People and Percentage of } \\
\text { Each Category }\end{array}$} & \multirow[t]{2}{*}{$\begin{array}{l}\text { Percentage } \\
\text { of Average }\end{array}$} & \multirow[t]{2}{*}{ Categori } \\
\hline & VS & $\mathrm{S}$ & ES & NS & DNS & & \\
\hline The role of farmer groups & 82 & 18 & 0 & 0 & 0 & 86,08 & VS \\
\hline $\begin{array}{l}\text { The role of agricultural } \\
\text { extension }\end{array}$ & 11 & 43 & 31 & 13 & 2 & 66,00 & ES \\
\hline The role of credit agencies & 7 & 20 & 45 & 23 & 5 & 57,60 & ES \\
\hline Institu & $\mathrm{al} \mathrm{El}$ & ront & tal & & & 68,89 & $\mathrm{~S}$ \\
\hline
\end{tabular}

Sources: Primary Data Analysis (2012)

Note: VS (Very Supports), S (Support), ES (enough support), NS (No Support), DNS (It Does Not Support)

\section{Farming Performance}

The first performance indicators onion farm is productivity. Based on the research productivity of minimum total of 61 quintals/hectares, while the maximum productivity is 131 quintals/hectare, average productivity is 92 quintals/hectares. Average productivity in Bantul be considered high when compared to productivity in other production centers such as Brebes district is 77.48 quintals/hectares at planting and in the same year (Kartikasari, 2012).

A second indicator is the income of farmers from farming of onion in Bantul average of Rp 25.868.109,27/hectares. The median income of farmers is large enough for onion price is quite high, averaging $\mathrm{Rp}$ 6579.00. According to farmers, the price level in the growing season I usually relatively better than the second season though not always the case.

A third indicator is the competitive advantage. The approach used to calculate the competitive advantage is through PCR (Private Cost Ratio). If the PCR value is less than one, indicating that a commodity is financially efficient and have a competitive advantage. The results obtained by the analysis of PCR values by 0,58 , which means to increase the revenue of $10.000,00$ required additional domestic factor costs of Rp 5.800,00 on financial prices, while the minimum and maximum competitive advantage respectively of 0.90 and 0.28. PCR value smaller than one indicates that the farming of onion in Bantul financially efficient and have a competitive advantage.

Table 8. Performance of Onion Farming Planting season of 2011 in Bantul

\begin{tabular}{lccc}
\hline \multicolumn{1}{c}{ Indicator } & \multicolumn{3}{c}{ Performance } \\
\cline { 2 - 4 } & Minimum & Maximum & Average \\
\hline Productivity quintals/hectares & 61 & 131 & 92 \\
Income Rp/hectares & 9.457 .461 & 57.420 .202 & $25.868 .109,27$ \\
Competitive Advantage & 0,90 & 0,28 & 0,58 \\
\hline
\end{tabular}

Sources: Primary Data Analysis (2012)

Influence Individual Factors, Social, Economic and Institutional Environmental to the Farmers Entrepreneurship and Its Effect on Performance of Onion Farming with Structural Equation Model Approach

\section{Confirmatory Factor Analysis - Exogenous Constructs}

Table 9. shows that almost all of the variables were analyzed to yield significant results or in other words is a good addition to forming constructs indicators X7 and X9. However, the value of $C R \geq 2,00$, the standardized regression weight $\geq 0,5$ and $p \leq 0,05$ indicates that the variable is still a good-forming constructs (Ghozali, 2011).

Table 10. shows the results of confirmatory factor analysis of the feasibility of this model exogenous constructs, it appears that most of the requirements are not fulfilled, namely probability, GFI and TLI. However, these values are close to the cut off value, and there are some goodness of fit index that has been fulfilled. In addition, the value of the standardized regression weight entirely $\geq 0,5$, so it is concluded that the 


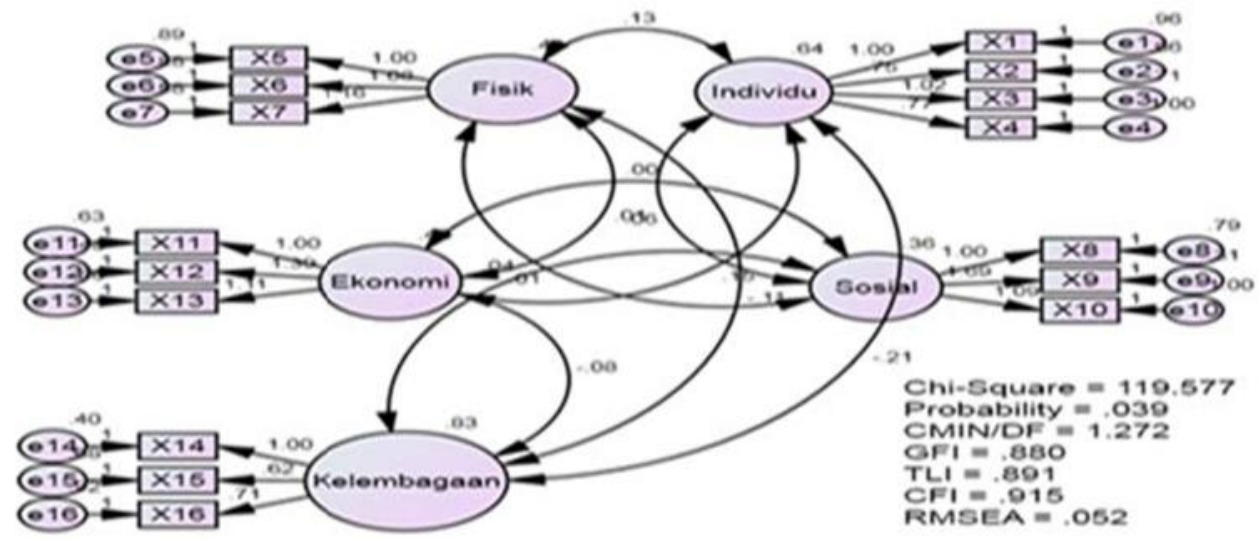

Figure 2. Confirmatory Factor Analysis Results Exogenous Constructs

Table 9. Regression and Standardized Regression Weight Exogenous Constructs in Confirmatory Analysis

\begin{tabular}{|c|c|c|c|c|c|c|c|}
\hline & & Estimatte & $\begin{array}{c}\text { Std. Regression } \\
\text { Weight }\end{array}$ & S.E. & C.R. & $P$ & Label \\
\hline $\mathrm{X} 12$ & <--- Economics & 1,394 & 0,811 & 0,293 & 4,760 & *** & par_1 \\
\hline X13 & $<---$ Economics & 1,110 & 0,685 & 0,214 & 5,197 & **** & par_2 \\
\hline $\mathrm{X} 11$ & <--- Economics & 1,000 & 0,656 & & & & \\
\hline $\mathrm{X} 5$ & <--- Phsycal & 1,000 & 0,570 & & & & \\
\hline X6 & <--- Phsycal & 1,077 & 0,601 & 0,301 & 3.571 & $* * *$ & par 3 \\
\hline $\mathrm{X} 7$ & <--- Phsycal & 1,157 & 0,707 & 0,369 & 3,139 & $* * *$ & par_4 \\
\hline $\mathrm{X} 2$ & $<---$ Individuals & 0,753 & 0,596 & 0,181 & 4,170 & $* * *$ & par_5 \\
\hline $\mathrm{X} 1$ & <--- Individuals & 1,000 & 0,632 & & & & \\
\hline X3 & <--- Individuals & 1,023 & 0,696 & 0,250 & 4,096 & $* * *$ & par_6 \\
\hline $\mathrm{X} 4$ & <--- Individuals & 0,765 & 0,522 & 0,192 & 3,986 & $* * *$ & par_7 \\
\hline $\mathrm{X} 10$ & $<---$ Social & 1,092 & 0,547 & 0,266 & 4,101 & $* * *$ & par_8 \\
\hline X9 & $<---$ Social & 1,688 & 0,876 & 0,532 & 3,175 & $* * *$ & par_9 \\
\hline X8 & $<---$ Social & 1,000 & 0,559 & & & & \\
\hline X16 & <--- Institutional & 0,709 & 0,560 & 0,207 & 3,422 & $* * *$ & par_10 \\
\hline $\mathrm{X} 17$ & <--- Institutional & 0,621 & 0,567 & 0,188 & 3,299 & $* * *$ & par_11 \\
\hline X14 & <--- Institutional & 1,000 & 0,824 & & & & \\
\hline
\end{tabular}

Source: Primary Data Processed, 2012

Notes: $* * *=$ Significant at $1 \%$ level

Table 10. Feasibility Testing Results Model on Exogenous Constructs

\begin{tabular}{cccc}
\hline Goodnes of Fit Index & Cut-Of Value & Analysis Result & Model Evaluation \\
\hline$X^{2}$-Chi-Square & Small Expected & 119,577 & Good \\
Probability & $\geq 0,05$ & 0,039 & Marginal \\
RMSEA & $\leq 0,08$ & 0,052 & Good \\
CMIN/DF & $\leq 2,0$ & 1,272 & Good \\
GFI & $\geq 0,90$ & 0,880 & Marginal \\
CFI & $\geq 0,90$ & 0,915 & Good \\
TLI & $\geq 0,90$ & 0,891 & Marginal \\
\hline
\end{tabular}

Source: Primary Data Processed, 2012 


\section{Confirmatory Factor Analysis - Endogenous Constructs}

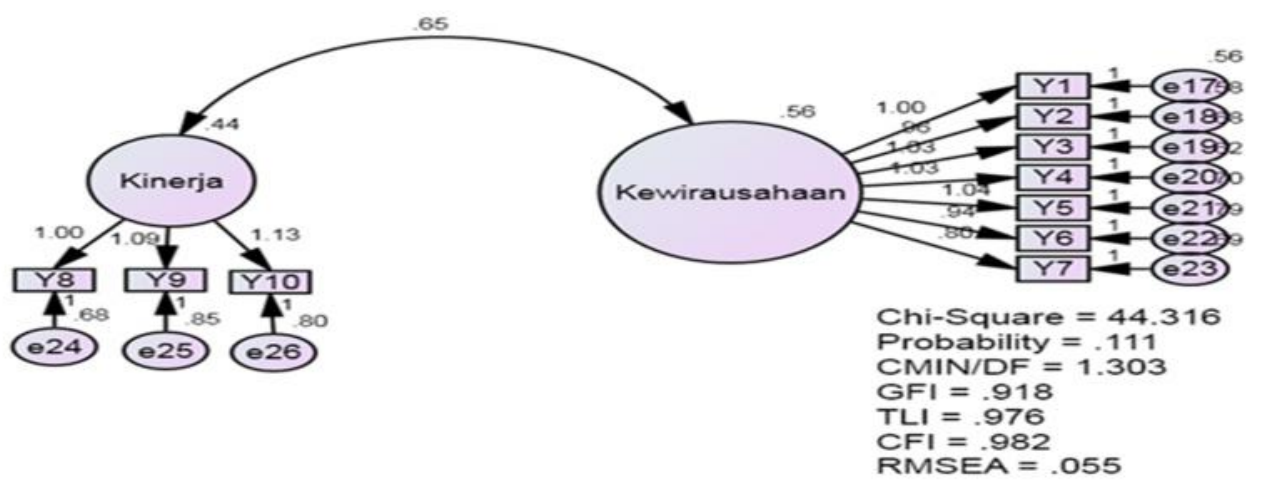

Figure 3. Confirmatory Factor Analysis Results Endogenous Constructs

Table 11. Regression and Standardized Regression Weight Exogenous Constructs in Confirmatory Analysis

\begin{tabular}{lrccccl}
\hline & Estimatte & $\begin{array}{c}\text { Std. Regression } \\
\text { Weight }\end{array}$ & S.E. & C.R. & $P$ & Label \\
\hline Y9 <--- Performance & 1,094 & 0,618 & 0,154 & 7,122 & $* * *$ & par_1 \\
Y10 <-- Performance & 1,129 & 0,642 & 0,155 & 7,284 & $* * *$ & par_2 \\
Y8 <--- Performance & 1,000 & 0,626 & & & & \\
Y1 <--- Entreprneurship & 1,000 & 0,707 & & & & \\
Y2 <--- Entreprneurship & 0,965 & 0,688 & 0,128 & 7,550 & $* * *$ & par_3 \\
Y3 <-- Entreprneurship & 1,026 & 0,683 & 0,137 & 7,499 & $* * *$ & par_4 \\
Y4 <--- Entreprneurship & 1,025 & 0,699 & 0,135 & 7,594 & $* * *$ & par_5 \\
Y5 <--- Entreprneurship & 1,043 & 0,684 & 0,139 & 7,518 & $* * *$ & par_6 \\
Y6 <--- Entreprneurship & 0,936 & 0,620 & 0,137 & 6,836 & $* * *$ & par_7 \\
Y7 <--- Entreprneurship & 0,800 & 0,585 & 0,124 & 6,473 & $* * *$ & par_8 \\
\hline Source Prin
\end{tabular}

Source: Primary Data Processed, 2012

Notes: $* * *=$ Significant at $1 \%$ level

Table 11. showed that the overall variables were analyzed to yield significant results or otherwise are forming a good construct for CR value $\geq 2.00$, the standardized regression weight $\geq$ 0.5 and $\mathrm{p} \leq 0.05$ indicates that the variable remains good construct forming .

Table 12. showed the results of the feasibility model of endogenous construct confirmatory factor analysis shows that all the requirements have been met as required. So it can be stated that the endogenous construct confirmatory factor analysis feasible in the model or in other words it can be stated that the indicators forming the construct of endogenous as strong indicators in the measurement model.

Table 12. Feasibility Testing Results Model on Endogenous Constructs

\begin{tabular}{lccc}
\hline \multicolumn{1}{c}{ Goodnes of Fit Index } & Cut-Of Value & Analysis Result & Model Evaluation \\
\hline$X^{2}$-Chi-Square & Small Expected & 44,316 & Good \\
Probability & $\geq 0,05$ & 0,111 & Good \\
RMSEA & $\leq 0,08$ & 0,055 & Good \\
CMIN/DF & $\leq 2,0$ & 1,303 & Good \\
GFI & $\geq 0,90$ & 0,918 & Good \\
CFI & $\geq 0,90$ & 0,982 & Good \\
TLI & $\geq 0,90$ & 0,976 & Good \\
\hline
\end{tabular}

Source: Primary Data Processed, 2012 


\section{Stuctural Equation Modelling (SEM) Analysis}

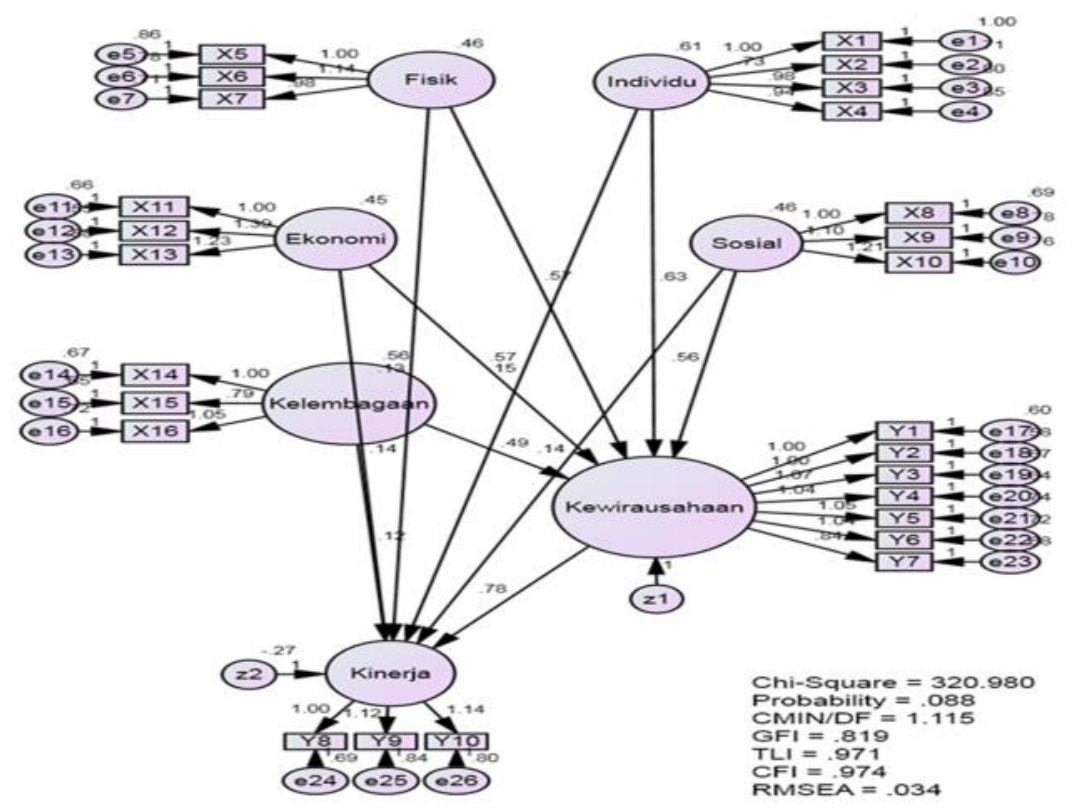

Figure 4.Stuctural Equation Modelling

Table 13. Feasibility Testing Results Model on Endogenous Constructs

\begin{tabular}{lccc}
\hline \multicolumn{1}{c}{ Goodnes of Fit Index } & Cut-Of Value & Analysis Result & Model Evaluation \\
\hline$X^{2}$-Chi-Square & Small Expected & 320,980 & Good \\
Probability & $\geq 0,05$ & 0,088 & Good \\
RMSEA & $\leq 0,08$ & 0,034 & Good \\
CMIN/DF & $\leq 2,0$ & 1,115 & Good \\
GFI & $\geq 0,90$ & 0,819 & Marginal \\
CFI & $\geq 0,90$ & 0,974 & Good \\
TLI & $\geq 0,90$ & 0,971 & Good \\
\hline
\end{tabular}

Source: Primary Data Processed, 2012

Table 13. showed that the goodness of fit test results SEM produces good fit indeces in the X2criterion Chi-Square Probability, RMSEA, $\mathrm{Cmin} / \mathrm{DF}$, CFI and TLI and marginal (approximately requirements) that GFI of 0.819 indicating that the model had a satisfactory match because probability values and structural model index is above the recommended level, this model is considered a reasonable representation of the data so no need to modify model.

Table 14 is the value of standardized regression weights indicate the individual and environmental factors influence the total positive and significant impact on entrepreneurial farmers and farm performance. In addition, entrepreneurial farmers also showed a positive and significant impact on farm performance. This is presumably due to individual factors and environmental conditions conducive to supporting the growth of entrepreneurial farmers and farm performance. So it can be concluded that the second and third research hypothesis is accepted.

Based on the analysis of the direct and indirect influence of individual and environmental factors have a significant and positive influence on entrepreneurial farmers and farm performance in Bantul onion. When compared to the direct influence of individual and environmental factors on farm performance was greater indirect influence (through entrepreneurship) so that it can be stated that entrepreneurship has an important role in mediating the influence of individual and environmental factors on farm performance. These results provide evidence for the idea that entrepreneurial farmers can be considered to be a new approach in improving farm performance. 


\section{Assumptions SEM Testing}

Tabel 14. Unstandardized dan Standardized Regression Weights in SEM Analysis

\begin{tabular}{|c|c|c|c|c|c|c|c|c|c|}
\hline \multicolumn{3}{|c|}{ Path } & Estimate & S.E & C.R & $\begin{array}{c}\text { Std. } \\
\text { Regression }\end{array}$ & $\mathrm{P}$ & Hypotesis & Note \\
\hline Entpnr & $<-$ & Individuals & 0.620 & 0.108 & 5.715 & 0.662 & $* * *$ & Two & Be accepted \\
\hline Entpnr & $<-$ & Physical & 0.547 & 0.108 & 5.067 & 0.513 & $* * *$ & Two & Be accepted \\
\hline Entpnr & $<-$ & Social & 0.529 & 0.096 & 5.512 & 0.494 & $* * *$ & Two & Be accepted \\
\hline Entpnr & $<-$ & Economics & 0.558 & 0.106 & 5.239 & 0.513 & $* * *$ & Two & Be accepted \\
\hline Entpnr & $<--$ & Institutonal & 0.565 & 0.101 & 5.604 & 0.585 & $* * *$ & Two & Be accepted \\
\hline Perform & $<-$ & Physical & 0.126 & 0.037 & 3.395 & 0.131 & $* * *$ & Two & Be accepted \\
\hline Perform & $<-$ & Individuals & 0.151 & 0.037 & 4.105 & 0.179 & $* * *$ & Two & Be accepted \\
\hline Perform & $<-$ & Socia & 0.135 & 0.035 & 3.814 & 0.141 & $* * *$ & Two & Be accepted \\
\hline Perform & $<--$ & Economics & 0.139 & 0.038 & 3.629 & 0.142 & $* * *$ & Two & Be accepted \\
\hline Perform & $<-$ & Institutional & 0.139 & 0.031 & 4.434 & 0.160 & $* * *$ & Two & Be accepted \\
\hline Perform & $<-$ & Entpnr & 0.781 & 0.097 & 8.069 & 0.868 & $* * *$ & Three & Be accepted \\
\hline
\end{tabular}

Source: Primary Data Processed, 2012

Notes: $* * *=$ Significant at $1 \%$ level

- Estimate = Unstandardized Regression Weights

- Std. Regression Weights $=$ Standardized Regression Weights

\section{Normality data}

The results of the normality analysis of the data showed that the value of CR skewness value all indicators point to a normal distribution because the value is below 2.58. While the multivariate normality test gives a value of 1.565 $\mathrm{CR}$ also below 2.58. So the multivariate normal distribution of data.

\section{Evaluation outlier}

The criteria used are based on the value of Chi-Squares on the degrees of freedom 26 (number of indicators) at a significance level of $\mathrm{p}$ $<0.001$. Value mahalonobis distance $\times 2(26,0,001)$ $=54.052$. This means that all the cases that have a distance mahalonobis> 54.052 were multivariate outliers.

\section{Evaluation of Multicollinearity and Singularity}

The results of data processing show the value of the sample covariance matrix determinant 4.856 away from zero so that it can be concluded that there is no multicollinearity and singularity problems in data analysis.

\section{Reliability, Variance Extract and Diskriminant Validity}

Table 15. showed that each construct has Construc Reliability, Variance Extract and Discriminant Validity good as required.

Table 15. Calculation results Construct Reliability, Variance Extract and Discriminant Validity

\begin{tabular}{lccc}
\hline \multicolumn{1}{c}{ Construct } & \multicolumn{3}{c}{ Value } \\
\cline { 2 - 4 } & Construct Reliability & Variance Extract & Discriminant Validity \\
\hline Individuals & 0.72 & 0.40 & 0.63 \\
Physical & 0.66 & 0.41 & 0.63 \\
Social & 0.70 & 0.65 & 0.65 \\
Economics & 0.76 & 0.72 & 0.72 \\
Institutional & 0.69 & 0.66 & 0.65 \\
Entrepreneurship & 0.85 & 0.67 & 0.67 \\
Performance & 0.66 & 0.63 & 0.63 \\
\hline
\end{tabular}

Source: Primary Data Processed, 2012 


\section{CONCLUSIONS}

1. The level of onion farmers entrepreneurship in Bantul categorized high overall average percentage of $70.87 \%$. The high level of entrepreneurship onion growers are very concerned with the characteristics of onion farming that requires intensive, capital intensive and high risk. Alloys of these is to encourage farmers to have attitudes that are indicators of entrepreneurship is a high need for achievement, having the confidence to be able to run the farm, the ability to bear risk, innovation, leadership, goal orientation and outcomes as well as market orientation.

2. Individual environmental factors, physical environment, social, economic and institutional positive and significant impact on the performance of entrepreneurial farmers and farming.It may prove that entrepreneurship is something that can be grown and developed with individual factors and environmental conditions that support.

3. Entrepreneurship farmer positive effect on farm performance and has an important role in mediating the influence of individual and environmental factors on farm performance. These results provide evidence for the idea that entrepreneurial farmers can be considered to be a new approach in improving farm performance.

\section{LITERATURE CITED}

Arikunto, S. 2002. Prosedur Penelitian Suatu Pendekatan Praktik. Rineka Cipta. Jakarta.

Ghozali, Imam. 2002. Aplikasi Analisis Multivariat dengan Program SPSS. Badan Penerbit Universitas Diponegoro.Semarang.

Ghozali, Imam. 2011. Model Persamaan Struktural Konsep dan Aplikas idengan Program Amos 19.0. Badan Penerbit Universitas Diponegoro. Semarang.

Kartika Sari, Maya. 2012. Efisiensi Produksi Bawang Merah di Kabupaten Brebes. Tesis. Program Pasca Sarjana Universitas Gadjah Mada. Yogyakarta. Tidak Dipublikasikan.

Priyanto, Sony Heru, 2004. Pengaruh Faktor Lingkungan, Kewirausahaan dan Kapasitas Manajemen Pada Petani Tembakau di Jawa Tengah. Disertasi. Tidak Dipublikasikan. Program Studi Ilmu Ekonomi Pasca Sarjana Universitas Brawijaya, Malang.

Wibowo, Rudi. 2005. State of The Arth Ilmu Ekonomi Pertanian Indonesia. Jurnal agroEkonomi. Edisi Khusus Tahun XXXV, Oktober 2005. 